\title{
Nursing Process for Elderly Women with Open Fractures, Victims of Violence: An Experience Report
}

\author{
Pablo Luiz Santos Couto"*, Alana Duque dos Santos ${ }^{2}$, Caroline Lorrane da Silva Goncalves ${ }^{2}$, \\ Samantha Souza da Costa Pereira ${ }^{1}$, Alba Benemérita Alves Vilela ${ }^{3}$, Magno Conceição das \\ Merces $^{4}$, Ricardo Bruno Santos Ferreira ${ }^{5}$, Yndira Yta Machado ${ }^{6}$, Beatriz Costa Pereira ${ }^{7}$, Paula \\ Luísa Lima Melo de Barros ${ }^{1}$ and Ishna Couto Sarmento ${ }^{8}$
}

${ }^{1}$ Nurse, master's in nursing, Higher Education Center of Guanambi, Brazil

${ }^{2}$ Nurse, State University of Bahia, Brazil

${ }^{3}$ Nurse, PhD in Nursing, State University of Southwest Bahia, Brazil

${ }^{4}$ Nurse, PhD in Health Sciences, State University of Bahia, Brazil

${ }^{5}$ Nurse, Master in Public Health, State University of Bahia, Brazil

${ }^{6}$ Nurse, Master in Nursing, State University of Rio de Janeiro, Brazil

${ }^{7}$ Psychology student, Higher Education Center of Guanambi, Brazil

${ }^{8}$ Specialist in Clinical and Laboratory Analysis. Bahia School of Medicine and Public Health, Brazil

*Corresponding author: Pablo Luiz Santos Couto, Nurse, Master in Nursing, Higher Education Center of Guanambi, Brazil

\section{ARTICLE INFO}

Received: 蔧 September 01, 2020

Published: 幽 September 14, 2020

Citation: Pablo Luiz Santos Couto, Alana Duque dos Santos, Caroline Lorrane da Silva Goncalves, Samantha Souza da Costa Pereira, Alba Benemérita Alves Vilela, et, al. Nursing Process for Elderly Women with Open Fractures, Victims of Violence: An Experience Report. Biomed J Sci \& Tech Res 30(3)-2020. BJSTR. MS.ID.004941.

Abbreviations: NCS: Nursing Care Systematization; NP: Nursing Process; DHS: Descriptors in Health Sciences; VHL: Virtual Health Library; NANDA: North American Classification of Nursing Diagnoses

\section{ABSTRACT}

Objective: to report the experience of the implementation and elaboration of the Nursing Process in the care of an elderly woman with an open fracture, victim of violence.

Method: a study carried out in the period of July 2019 after providing care to an elderly victim of violence in the Surgical Clinic sector of a public hospital, during the curricular practices of the Nursing course. The needs were raised with the help of a checklist adopted for the admission of patients to the sector.

Results: it appears that the implementation of the stages of the nursing process helps nurses in improving care practice, with the survey of needs (anxiety, insomnia, low self-esteem, pain, immobility, bed restraint, difficulty in bathing, risk of skin pressure injury and infection, deficient nutritional intake, weight loss), which presented the main nursing diagnoses, allowing greater professional autonomy, recognition by clients and, consequently, positive prognosis of health conditions.

Conclusion: It is concluded that the delimitation of nursing diagnoses, planning of results and prescription of nursing interventions from this study, led to the perception that the needs of elderly women refer to subjective issues (consequences of violence), in addition to the physiological aspects, including in the hospital environment.

Keywords: Nursing Care; Nursing Process; Aging; Violence Against Women

\section{Mini Review}

Population aging is defined by the modification of the age structure, characterized by an increase in the number of individuals over 60 years or older [1]. During the period from 2005 to 2015, there was an increase in Brazil from $9.8 \%$ to $14.3 \%$ in the age group of 60 years or more [2], with a higher percentage of the female

audience (56\%), in relation to the male (44\%) [3]. The feminization of old age predisposes elderly women to social vulnerability, since in general, women face social, political and economic inequalities and, above all, gender, spanning all generation $[1,4,5]$. A study carried out in Portugal inferred that $76.1 \%$ of the victims of violence 
in the elderly were women [6]. The violence is a complex and multifaceted phenomenon, which is found in several forms (aggression, psychological, sexual, abandonment, financial), results in or has a high risk of death, injury, psychological damage, with repercussions on the victims' quality of life [5,7]. Physical violence, when force is used to cause harm $[7,8]$, is the most evident, corresponding to between $56 \%$ and $87.8 \%$ of cases $[5,6]$. Thus, the damage resulting from violence results in fractures, a consequence of several other risks (falls, domestic accidents, musculoskeletal problems) that the elderly are subject to since it is a common problem in the elderly $[7,8]$.

The nursing team must be able to use the Nursing Care Systematization (NCS), which organizes the professional work regarding the method, guiding the nursing actions and ensuring the client a holistic care, so that the nurse must recognize the problems related to violence against elderly people [9]. To do so, it has the operationalization of the Nursing Process (NP), using its five guiding steps, from investigation or history with detecting the patient's problems, description of the nursing diagnoses, planning the expected results until the implementation of care and the assessment of the goals set and the patient's evolution [10]. Thus, the objective of this study is to report the experience of the implementation and elaboration of the Nursing Process in the care of an elderly woman with an open fracture, a victim of violence.

\section{Method}

It is an experience report on the elaboration of the stages of the nursing process to an elderly woman, living in the rural area of the state of Bahia, with low level of education and socioeconomic status, married and with seven children, who presented an open fracture in left lower limb, victim of domestic violence (she was hit by her partner, according to the patient's information). This study was carried out in the period of July 2019 after providing care to a patient at the Surgical Clinic of a public hospital, the main of the Alto Sertão Produtivo Bahia, during the curricular practices of the Bachelor of Nursing course. Thus, the elaboration of the NP was carried out, based on information on the patient's needs, through a checklist adopted by the hospital in question, which is adopted on the admission of any patient in the sector, bringing a possible plan of care for the patient victim of an exposed fracture resulting from violence based on the needs presented. In this sense, in addition to the information on the checklist, which was constituted as data for the construction of the results, the search for scientific articles was carried out, to subsidize the care to be implemented and to base the reflection and discussion of the results, from the Descriptors in Health Sciences (DHS): Aging AND ("open fracture" OR violence), Nursing care or Nursing Process AND violence, in the Virtual Health Library (VHL) database. Then, with the elements contained in the patient's admission history, health needs were described, the delimitation of diagnoses, based on the North American Classification of Nursing Diagnoses (NANDA) 2018-2020, elaboration of the care plan for interventions and evaluation of the results for each diagnosis, based on the articles shown in the VHL [11], as shown in Tables $1 \& 2$.

By using only publicly available data, without identifying the person and without risk to the study patient, being public domain data, submission to the Research Ethics Committee (CEP) was waived.

\section{Results}

During the practice period in the surgical clinic, there was a need to discuss nursing care for a patient victim of violence with open fractures or any other type of physical injury, as well as to elaborate nursing diagnoses to determine an appropriate care plan for choosing interventions and expected results as set out in the two (Tables 1 \& 2) below.

Table 1: Stages of the nursing process related to the consequences of violence suffered by elderly women.

\begin{tabular}{|c|c|c|c|}
\hline Problems / needs & Nursing diagnoses - NANDA-I & Nursing interventions \\
\hline Anxiety & $\begin{array}{c}\text { Anxiety, related to death threat, characterized } \\
\text { by increased tension. }\end{array}$ & $\begin{array}{c}\text { Effer psychological support, promote a } \\
\text { calm and peaceful environment. }\end{array}$ & $\begin{array}{c}\text { You will look relaxed and your } \\
\text { anxiety will be eased to a bearable } \\
\text { level. }\end{array}$ \\
\hline Insomnia & $\begin{array}{c}\text { Sleep pattern disorder related to non- } \\
\text { restorative sleep pattern characterized by } \\
\text { difficulty maintaining sleep. }\end{array}$ & $\begin{array}{c}\text { Assist in stressful situations before } \\
\text { bedtime; Discuss comfort measures } \\
\text { and lifestyle changes with the patient / } \\
\text { Family. }\end{array}$ \\
\hline Low self-esteem & $\begin{array}{c}\text { Low situational self-esteem, related to a pattern } \\
\text { of helplessness characterized by self-negative } \\
\text { verbalizations. }\end{array}$ & $\begin{array}{c}\text { Search support groups; Encourage the } \\
\text { identification of specific life values. }\end{array}$ \\
\hline
\end{tabular}

Table 2: Steps in the nursing process related to the consequences of open fracture suffered by elderly women.

\begin{tabular}{|c|c|c|c|}
\hline Problems / needs & Nursing diagnoses -NANDA-I & Nursing interventions \\
\hline Pain & $\begin{array}{c}\text { Acute pain associated with open } \\
\text { fracture, characterized by verbal report } \\
\text { of pain. }\end{array}$ & $\begin{array}{c}\text { Assist in the elaboration of the medication } \\
\text { therapeutic plan for pain relief; }\end{array}$ \\
$\begin{array}{c}\text { Control environmental factors capable of } \\
\text { intensifying pain. }\end{array}$ \\
\hline
\end{tabular}




\begin{tabular}{|c|c|c|c|}
\hline $\begin{array}{l}\text { Immobility; restriction } \\
\text { to bed }\end{array}$ & $\begin{array}{l}\text { Impaired bed mobility related to pain } \\
\text { and musculoskeletal impairment, } \\
\text { evidenced by impaired ability to } \\
\text { reposition in bed. }\end{array}$ & $\begin{array}{l}\text { To assist in walking and activities; To refer } \\
\text { and Collaborate with the physiotherapist in } \\
\text { the development of an exercise program. }\end{array}$ & $\begin{array}{l}\text { It will demonstrate techniques } \\
\text { and behaviors that enable the } \\
\text { resumption of its activities. }\end{array}$ \\
\hline $\begin{array}{l}\text { risk of skin pressure } \\
\text { injury }\end{array}$ & $\begin{array}{l}\text { Risk of impaired skin integrity } \\
\text { associated with reduced physical } \\
\text { mobility in bed. }\end{array}$ & $\begin{array}{l}\text { Pay attention to the appearance of ischemic } \\
\text { regions in the limbs; Perform the decubitus } \\
\text { change ( } 3 \text { / 3h); } \\
\text { Provide an appropriate mattress to relieve } \\
\text { pressure on the skin; Daily monitor the skin } \\
\text { and mucous membranes. }\end{array}$ & $\begin{array}{l}\text { It will present a reduced risk of } \\
\text { damaging the skin during the } \\
\text { hospital stay. }\end{array}$ \\
\hline difficulty bathing & $\begin{array}{l}\text { Deficit in self-care for the bath } \\
\text { associated with musculoskeletal } \\
\text { impairment due to the fracture, } \\
\text { evidenced by the inability to perform } \\
\text { self-hygienization. }\end{array}$ & $\begin{array}{l}\text { Perform the person's bath in bed; } \\
\text { Promote oral hygiene; } \\
\text { Monitor skin conditions while bathing. }\end{array}$ & $\begin{array}{l}\text { You will have your body hygiene } \\
\text { performed effectively with the } \\
\text { help of the nursing team. }\end{array}$ \\
\hline Risk of infection & $\begin{array}{l}\text { Risk of infection related to the } \\
\text { intravenous catheter and prolonged } \\
\text { hospital stay. }\end{array}$ & $\begin{array}{l}\text { Wash hands before and after each patient } \\
\text { care activity. }\end{array}$ & $\begin{array}{l}\text { It will present a reduced risk of } \\
\text { acquiring infection. }\end{array}$ \\
\hline $\begin{array}{l}\text { Deficient nutritional } \\
\text { intake; Slimming }\end{array}$ & $\begin{array}{l}\text { Imbalanced nutrition: less than the } \\
\text { bodily needs related to lack of appetite, } \\
\text { characterized by loss of interest in food } \\
\text { and weight loss. }\end{array}$ & $\begin{array}{l}\text { Request the support and attention of the } \\
\text { nutrition team; } \\
\text { Assist in the elaboration of the food plan } \\
\text { consistent with the current clinical condition. }\end{array}$ & $\begin{array}{l}\text { It will demonstrate an increased } \\
\text { appetite during meals offered } \\
\text { in order to satisfy your bodily } \\
\text { needs in order to prevent weight } \\
\text { loss. }\end{array}$ \\
\hline
\end{tabular}

\section{Discussion}

In any care environment, nurses have an outstanding role in caring for elderly people who are victims of violence, mainly because they have greater contact with the community within health institutions and are primarily responsible for the development of NP, in order to guarantee a well-founded practice. at (NCS), in addition to being frequently the first professional to identify situations of violence $[7,12]$. It is emphasized that the systematization of the assistance made possible by the NP, will allow safe and adequate care to the needs and singularities of any person, as it will direct the entire team to do the service with quality [10]. With regard to cases of domestic and gender violence, nursing care has a challenging role in caring for the victim, as it is possible to observe changes and developments, whether physical as in the case of open fractures, or emotional, in which the NCS makes it possible to identify and adequately care for the problems arising from violence with emotional support, as well as to stimulate the denunciation as well as make the notification [13].

When addressing the topic of physical violence, it should be noted that in addition to physical damage, it is common for psychological / emotional disorders to arise which can evolve into more serious problems, so it is necessary to make a careful assessment with the collection of information on admission along with the history / investigation [7]. In physical disorders, in turn, the individual's mobility, functional independence, and self-care will be compromised after an open fracture, which changes their daily routine and prevents them from performing activities that require mobility, making them dependent on others and restricted. to the bed [14].

The sleep and rest pattern of people who suffered an open fracture is also impaired due to pain [15]. Despite the prescribed pharmacotherapy, pain control is difficult due to environmental factors capable of intensifying it or the psychic disorders that lead to the somatization of symptoms [13].

With regard to the risk of nosocomial infection, the longevity associated with chronic diseases consists of the main risk factors; patients with open fractures have a surgical site, as well as a prolonged period of hospital stay using a peripheral venous catheter, making them susceptible to infection. Thus, the importance of adopting aseptic techniques that ensures patient safety in the prevention of care-related infection is highlighted [16]. Given the senescence and senility process of elderly patients, their recovery is slow and the possibility of developing complications such as pressure injuries is high, making it necessary to pay extra attention to the care in preventing skin injuries resulting from the hospitalization period [17].

\section{Conclusion}

It is concluded that the search for diagnoses, results and nursing interventions from this study, enabled a more in-depth knowledge about the care for patients with open fracture injuries victims of domestic violence, as well as showing the relevance of providing assistance systematized nursing, for the elderly woman's positive prognosis, including psychic / emotional aspects, in addition to the physiological ones. The problems / needs perceived in the experience of implementing the nursing process are individual and unique to each person with health problems, which reinforces the nurse's need to delimit nursing diagnoses and prescribe a care plan congruent with the individuality of each human being in need of nursing care. The needs raised here are aimed only at the client and refer only to her: anxiety, insomnia, low self-esteem, pain, immobility, bed restraint, difficulty in bathing, risk of injury by pressure on the skin and infection, deficient nutritional intake, 
slimming. In other words, other people may have such needs or not, and it will depend on each person's coping. It is suggested to nursing professionals, specifically the nurse, the constant use of the Nursing Process, in order to guarantee a holistic view and individualized care, to reduce intra-hospital occurrences, such as prolongation in the hospitalization period and worsening of the condition patient's clinical status.

\section{References}

1. Silva AR, Sampaio LS, Reis LA, Sampaio TSO (2017) Violence Against Elderly: Association Between the Gender of the Aggressors and the Type of Violence. Journal Of Psychology 11(38).

2. (2016) Take a look at the social indicators in an analysis of the living conditions of the Brazilian population.

3. (2018) Number of elderly people grows $18 \%$ in 5 years and exceeds 30 million in 2017.

4. Almeida AV, Mafra SCT, Silva EP, Kanso AS (2019) The Feminization of Old Age: a focus on the socioeconomic, personal and family characteristics of the elderly and the social risk. 14(1).

5. Rocha EN, Vilela ABA, Silva DM (2015) Confronting intrafamily violence against older people by health professionals. 18(4).

6. Gil AP, Santos AJ, Kislaya I (2015) Study on elderly people victims of violence in Portugal: sociography of the occurrence. 31(6): 1234-1246.

7. Faustino AM, Gandolfi L, Moura LB (2014) Functional capability and violence situations against the elderly. 27(5).

\section{ISSN: 2574-1241}

\section{DOI: $10.26717 / B J S T R .2020 .30 .004941$}

Pablo Luiz Santos Couto. Biomed J Sci \& Tech Res

(C) (P) This work is licensed under Creative

Submission Link: https://biomedres.us/submit-manuscript.php
8. Batista AC, Divino AEA, Martins MCV (2017) A Sistematização da Assistência de Enfermagem did not attend to women victims of violence. 9(12).

9. (2018) Result of the Search for: Conselho Federal de Enfermagem. Resolution COFEN-311.

10. (2009) Conselho Federal de Enfermagem. Resolução Cofen-358/2009.

11. T Heather Herdman, Shigemi Kamitsuru, Nanda International (2017) Nursing Diagnoses: Definitions \& Classification 2018-2020, Eleventh Edition.

12. Salvador PTCO, Santos VEP, Zeferino MT (2015) Ideal type of nursing students regarding nursing care systematization. Rev Mineira Enferm 19(2).

13. Cortez LF, Padoin SMM Vieira LB, Letícia Becker Vieira, Maria Celeste Landerdahl, Jaqueline Arboit (2019) C Care for women victims of violence: empowering nurses in the pursuit of gender equity. Rev. Gaúcha Enferm. 36(esp).

14. Fonseca MA, Matias AGC, Silva Santos WS (2018) Structure Of The Social Representation of Lower Limb Fractures In Hospitalized Individuals. Rev Patol Tocantins 5(1).

15. Silva MR da, Silva DO, Santos EC dos (2017) Diagnoses, results and nursing interventions for people submitted to orthopedic and traumatological surgeries. Journal of Nursing.

16. National Health Surveillance Agency. Measures for the prevention of infection related to health care.

17. Soares CF, Heidemann ITSB (2018) Health promotion and prevention of pressure injury: Expectations of primary health care nurses. Texto Contexto Enferm. 27(2).

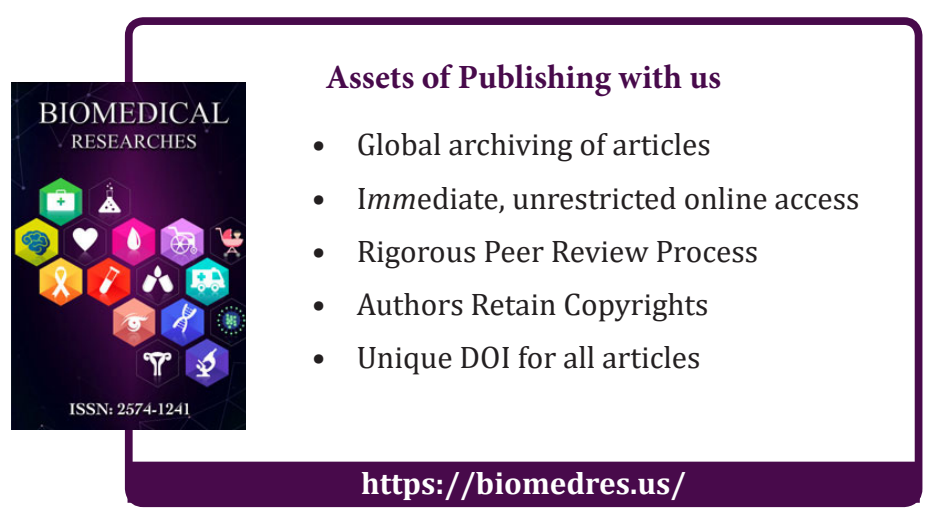

